\title{
IQTISHODUNA
}

Vol. 17 (2), 2021

P-ISSN: 1829-524X, E-ISSN: 26143437

\section{Pengaruh Gaya Kepemimpinan Transaksional, Penempatan Kerja dan Iklim Kerja Terhadap Kinerja Karyawan}

\author{
Agusthina Risambessy ${ }^{1}$, Paulus L. Wairisal ${ }^{2}$, \\ 1,2Universitas Pattimura, Jl. Ir. M. Putuhena, Poka, Tlk. Ambon, Indonesia
}

$\triangle$ Corresponding Author:

Nama Penulis: Paulus L. Wairisal

E-mail: liberthyw@gmail.com

\begin{abstract}
The problem of the quality of human resources is the most important part for every company, both government and private. This study aims to analyze and explain the effect of transactional leadership style on employee performance, job placement on employee performance and work climate on employee performance. This research is located at PT.Bank Modern Express Ambon. The research population is all permanent employees of PT.Bank Modern Express Ambon. The sample used is 94 people, using the saturated sampling technique. Multiple linear regression analysis methods. The results of the study prove that transactional leadership style with contingent reward indicators, active expectations management indicators, passive exception management indicators, have a significant positive effect on the performance of PT. Modern Express Bank Ambon. Work placement with indicators of education, skills, and physical and mental health has a significant positive effect on the performance of employees of PT. Modern Express Bank Ambon. Work climate using indicators of compensation, cooperation, work suitability, division of tasks, and organizational policies have a significant positive effect on the performance of employees of PT. Modern Express Bank Ambon.
\end{abstract}

Keywords: Transactional Leadership Style, Placement, Work Climate, and Employee Performance

Abstrak: Masalah kualitas sumberdaya manusia menjadi bagian terpenting bagi setiap perusahaan baik Pemerintah maupun Swasta. Penelitian ini bertujuan untuk menganalisis dan menjelaskan pengaruh gaya kepemimpinan transaksional terhadap kinerja karyawan, penempatan kerja terhadap kinerja karyawan dan iklim kerja terhadap kinerja karyawan. Penelitian ini berlokasi pada PT.Bank Modern Express Ambon. Populasi penelitian yakni semua karyawan tetap PT.Bank Modern Express Ambon. Sampel yang digunakan berjumlah 94 orang, menggunakan tehnik pengambilan sampel jenuh. Metode analisis Linier Regresi berganda. Hasil penelitian membuktikan bahwa Gaya kepeminpinan transaksional dengan indikator imbalan kontingen indikator manajemen ekspetasi aktif indikator manajemen eksepsi pasif berpengaruh positif signifikan terhadap kinerja karyawan PT. Bank Modern Express Ambon. Penempatan kerja dengan indicator pendidikan, ketrampilan, dan kesehatan 
Agusthina Risambessy, Paulus L. Wairisal

fisik dan mental berpengaruh positif signifikan terhadap kinerja karyawan PT. Bank Modern Express Ambon. Iklim kerja menggunakan indikator kompensasi, kerjasama, kesesuaian kerja, pembagian tugas, dan kebijakan organisasi berpengaruh positif signifikan terhadap kinerja karyawan PT. Bank Modern Express Ambon.

Kata kunci: Gaya Kepemimpinan Transaksional, Penempatan, Iklim Kerja, Kinerja Karyawan

|Submit 28 Februari 2021|Diterima 20 Oktober 2021| Terbit 31 Oktober 2021|

\section{Cara mensitasi:}

Risambessy, A. Wairisal, P. L. (2021). Pengaruh Gaya Kepemimpinan Transaksional, Penempatan Kerja dan Iklim Kerja Terhadap Kinerja Karyawan. Iqtishoduna. Vol. 17 (2): pp 175-189

\section{PENDAHULUAN}

Era globalisasi turut mempengaruhi perekonomian nasional Indonesia. Dampak langsung yang dirasakan adalah adanya perkembangan dunia usaha dalam negeri yang mengalami kemajuan baik yang dilakukan pemerintah maupun swasta. Pemerintah member keleluasaan kepada pihak swasta untuk ikut berperan serta dalam peningkatan pembangunan serta perekonomian bangsa. Sumber daya manusia (SDM) merupakan faktor sentral dalam suatu organisasi. Apapun bentuk dan tujuannya, suatu organisasi didirikan berdasarkan visi untuk kepentingan bersama, dan dalam pelaksanaan misinya dikelola dan diurus oleh manusia. Tenaga kerja atau karyawan merupakan sumber yang paling berharga didalam organisasi. Tanpa adanya tenaga kerja atau karyawan yang berkualitas mustahil tujuan organisasi dapat tercapai dengan baik.

PT. BPR Modern Express merupakan perusahaan perbankan yang terletak di Kota Ambon telah berdiri sejak tahun 1988 dan mempunyai beberapa cabang antara lain di Tual, Masohi, Namlea, Piru, Saumlaki dan Piru. Dalam persaingan yang kian ramai seiring dengan banyaknya bank-bank umum, Pada dasarnya ada empat layanan Produk PT BPR Modern Express yaitu : (1) Kredit konsumsi: memberikan kredit kepada masyarakat dalam pembiayaan konsumtif pribadi, seperti kredit khusus pegawai negeri, pensiunan, kepemilikan kendaraan; (2) Kredit Modal Kerja: memberikan kredit kepada masyarakat untuk pemberdayaan modal, (3) Deposito adalah simpanan berjangka bagi masyarakat / perusahaan dan (4) Tabungan adalah tabungan umum bagi masyarakat / perusahaan.

Struktur kepegawaian pada BPR Modern Express terdiri dari komisaris, direksi, manajer, kepala cabang dan satuan pengawas internal. Dimana manajer terdiri dari manajer operasional dan manajer manajer kredit. 
Pengaruh Gaya Kepemimpinan Transaksional... Manajer operasional membawahi bagian dana, akuntansi, informatika dan teknologi (IT) dan umum. Manajer kredit membawahi bagian kredit, marketing dan penagihan (kolektor). Kepemimpinan sebagai sebuah fenomena kompleks memerlukan proses yang terencana, teratur, berkelanjutan dan berkesinambungan. Gaya kepemimpinan transaksional merupakan gaya kepemimpinan yang menghubungkan pimpinan dengan bawahan dalam sebuah transaksi (transaction). Gaya ini digunakan untuk membawah setiap dalam satu alur pemikiran tentang hasil yang harus dicapai.

Manajemen Bank Perkreditan Rakyat Modern Express dalam menentukan kinerja karyawan melalui penilaian kinerja pegawai yang meliputi sasaran kerja individu, ketrampilan kunci dan kompetensi dengan pembobotan tertentu sehingga menghasilkan hasil kinerja karyawan dengan klasifikasi pembobotan: A (Istimewa), B (Baik), C (Cukup), dan D (Kurang). Penilaian kinerja karyawan di BPR Modern Express yang terdiri dari tiga kriteria sasaran kerja individual, ketrampilan kunci, dan kompetensi dengan pembobotan tertentu sehingga kinerja karyawan diukur dengan pembobotan criteria A, B, C dan D sangat tergantung dari masing-masing individunya sedangkan faktor eksternal diluar individunya tidak diperhatikan yaitu gaya kepemimpinan, komunikasi dan iklim kerja sehingga kajian kinerja karyawan yang berkaitan dengan gaya kepemimpinan, komunikasi dan iklim kerja perlu dilakukan.

Berdasarkan informasi Biro Riset Info Bank (birI) dalam majalah info bank, yang ditunjukkan pada tabel diatas dari 367 Bank Perkreditan Rakyat di Indonesia, PT BPR Modern Express Ambon menjadi salah satu dari 10 BPR Terbaik bahkan menempati posisi pertama sebagai Bank Perkreditan Rakyat Terbaik 2014 yang beraset Rp.500 Miliar ke atas, dengan predikat sangat bagus. Walaupun demikian, belum menunjukan kinerja yang optimal karena masih ada nilai D bagi 21 karyawan dan tidak ada yang diklasifikasikan dengan nilai A. Hal ini menimbulkan pertanyaan bagi peneliti mengenai pengukuran kinerja di Bank Perkreditan Rakyat Modern Express sehingga perlu dikaji kembali agar kinerja karyawan bisa lebih optimum.

Penelitian yang dilakukan oleh Hartini Natalia \& Hari Murti (2018) pada staf/karyawan PD. BPR Bank Jogja Kota Yogyakarta, menunjukan bahwa gaya kepemimpinan transaksional berpengaruh positif terhadap kinerja karyawan, penempatan kerja dan iklim kerja dimediasi oleh komitmen organisasi berpengaruh terhadap kinerja karyawan. Penelitian Hasbala dan Ambarini (2019) pada karyawan Pabrik Keramik di Mojosari, menunjukan hasil yang bertantangan dimana gaya kepemimpinan transaksional berpengaruh negative pada kinerja karyawan. Penerapan gaya kepemimpinan transkasional yang dilakukan untuk menekan karyawan berusaha untuk meningkatkan laba perusahaan akan menghasilkan kinerja yang buruk karena tidak ada karyawan yang mau hidup dan bekarja setiap hari dibawa tekanan. Sementara penempatan kerja dan iklim kerja berpengaruh positif terhadap kepuasan dan kinerja karyawan.

Ketidakkonsistenan hasil penelitian diatas, maka penelitian ini tidak menggunakan variable mediasi tetapi menggunakan uji parsial pada masingmasing variabel. Peneltian yang dilakukan oleh Cherly Takandengan, Marli 
Agusthina Risambessy, Paulus L. Wairisal

dan Sarli (2019) pada karyawan kantor Pertanahan Provinsi Sumatra Utara membuktikan bahwa gaya kepemimpinan transaksional berpengaruh signifikan positif terhadap kinerja karyawan, penempatan berpengaruh signifikan terhadap kinerja karyawan. Hal ini menunjukan bahwa penempatan orag yang tetap pada pekerjaan yang tepat maka akan meningkatkan kinerja karyawan. Iklim kerja yang baik didukung oleh pemimpin yang berwibawa akan menciptakan suasana kerja yang nyaman, maka kinerja akan meningkat.

Penelitian yang dilakukan Kamerusaman dan Dwihartini (2020) pada karyawan PT. Anugrah Lahan Sibela Maluku Utara, ditemukan pula bahwa gaya kepemimpinan transaksional dan transformasional, kemampuan kerja dan iklim kerja mempunyai pengaruh signifikan positif terhadap kinerja karyawan. Hal ini menunjukan bahwa gaya kepemimpinan transaksional dinilai oleh karyawan bukan sebagai tekanan tetapi motivasi untuk karyawan lebih tekun bekerja untuk meningkatkan kinerja. Adapun rumusan penelitian sebagai berikut: Penelitian ini bertujuan untuk mengetahui Pengaruh gaya kepemimpinan transaksional terhadap kinerja karyawan PT. Bank Modern Express Ambon, Apakah Pengaruh penempatan kerja terhadap kinerja karyawan PT. Bank Modern Express Ambon. Apakah Pengaruh iklim kerja terhadap kinerja karyawan PT. Bank Modern Express Ambon.

\section{KAJIAN PUSTAKA \\ Kepemimpinan Transaksional}

Burns (1978) dalam Farida (2017) mendefinisikan kepemimpinan transaksional sebagai bentuk hubungan yang mempertukarkan jabatan atau tugas tersebut. Jadi, kepemimpinan transaksional menekankan proses hubungan pertukaran yang bernilai ekonomis untuk memenuhi kebutuhan biologis dan psikologis sesuai dengan kontrak yang telah mereka setujui bersama. Bass (1990) dalam (Farida 2017) mengemukakan kepemimpinan transaksional yang didefinisikan sebagai kepemimpinan yang melibatkan suatu proses pertukaran yang menyebabkan bawahan mendapat imbalan serta membantu bawahannya mengidentifikasikan apa yang harus dilakukan untuk memenuhi hasil yang diharapkan seperti kualitas pengeluaran yang lebih baik, penjualan atau pelayanan yang lebih dari karyawan, serta mengurangi biaya produksi.

\section{Gaya kepemimpinan transaksional}

Tipe atau gaya kepemimpinan transaksional meliputi dimensi: (1) Contigent Reward (Penghargaan rombongan). Pemimpin memperjelas pekerjaan yang harus di lakukan menggunakan insentif sebagai alat mendorong pencapaiaan hasil pelaksanaan tugas sesuai harapan serta (2) Management By Exception (Manajemen Dengan Pengecualian). Secara pasif, pemimpin menggunakan upaya koreksi/Hukuman sebagai respons terhadap kinerja buruk/penyimpangan terhadap standard. Secara aktif mempengaruhi perilaku pemimpin secara aktif melakukan pemantauan terhadap perkerjaan yang dilakukan karyawan dan menggunakan upaya korektif dalam rangka memastikan bahwa pekerjaan di lakukan dan diselesaikan sesuai standar. 
Pengaruh Gaya Kepemimpinan Transaksional...

Pengadaan Imbalan, pemimpin menggunakan serangkaian imbalan untuk mekomunikasi para anggota, Imbalannya berupa kebutuhan tingkat fisiologis (maslow). Eksepsi/pengecualian, dimana pemimpin akan memberi tindakankoreksi atau pembatalan imbalan atau sanksi apabila anggota gagalmencapai sasaran prestasi yang ditetapkan. Karakteristik kepemimpinan transaksionalis antara lain: a) Mengetahui keinginan bawahan b) Terampil Memberikan imbalan atau janji yang tepat dan c) Responsif terhadap kepentingan bawahan.

\section{Faktor-Faktor Pembentuk Gaya Kepemimpinan Transaksional}

Faktor-faktor pembentuk gaya kepemimpinan transaksional menunjuk pada hal-hal yang dilakukan pemimpin dalam penerapannya. Menurut Burns (dalam Farida 2017), suatu gaya kepemimpinan memiliki faktor-faktor yang menunjukkan gaya seorang pemimpin dalam memotivasi bawahannya. Upaya memotivasi bawahan agar menjadi efektif dilakukan dengan mempengaruhi bawahan agar bertindak sesuai dengan waktu dan saling kooperatif untuk mencapai tujuan. Gaya kepemimpinan transaksional menurut Bass at.al. (2003) dibentuk oleh faktor-faktor yang berupa imbalan kontingen (contingent reward), manajemen eksepsi aktif (active management by exception), dan manajemen eksepsi pasif (passive management by exception). Imbalan Kontingen (Contingent Reward). Faktor ini dimaksudkan bahwa bawahan memperoleh pengarahan dari pemimpi mengenai prosedur pelaksanaan tugas dan target-target yang harus dicapai. Bawaan akan menerima imbalan dari pemimpin sesuai dengan kemampuannya dalam mematuhi prosedur tugas dan keberhasilannya mencapai target-target yang telah ditentukan.

Manajemen eksepsi aktif (active management by exception). Faktor ini menjelaskan tingkah laku pemimpin yang selalu melakukan pengawasan secara direktif terhadap bawahannya. Pengawasan direktif yang dimaksud adalah mengawasi proses pelaksanaan tugas bawahan secara langsung. Hal ini bertujuan untuk mengantisipasi dan meminimalkan tingkat kesalahan yang timbul selama proses kerja berlangsung. Seorang pemimpin transaksional tidak segan mengoreksi dan mengevaluasi langsung kinerja bawahan meskipun proses kerja belum selesai. Tindakan tersebut dimaksud agarbawahan mampu bekeja sesuai dengan standar dan prosedur kerja yang telah ditetapkan. Manajemen eksepsi pasif (passive management by exception) Seorang pemimpin transaksional akan memberikan peringatan dan sanksi kepada bawahannya apabila terjadi kesalahan dalam proses yang dilakukan oleh bawahan yang bersangkutan. Namun apabila proses kerja yang dilaksanaka masih berjalan sesuai standar dan prosedur, maka pemimpin transaksional tidak memberikan evaluasi apapun kepada bawahan.

\section{Penempatan Karyawan}

Menurut Marihot T. E. Hariandja (2005) dalam Doni (2019) menyatakan bahwa: "Penempatan merupakan proses penugasan/ pengisian jabatan atau penugasan kembali pegawai pada tugas/ jabatan baru atau jabatan yang berbeda". Mathis \& Jackson (2006) dalam Doni (2019) menyatakan bahwa: 
Agusthina Risambessy, Paulus L. Wairisal

"Penempatan adalah menempatkan posisi seseeorang ke posisi pekerjaan yang tepat, seberapa baik seorang karyawan cocok dengan pekerjaanya akan mempengaruhi jumlah dan kualitas pekerjaan. B. Siswanto Sastrohadiryo yang dikutp oleh Suwatno (2003:138) "Penempatan pegawai adalah untuk menempatkan pegawai sebagai unsur pelakasana pekerjaan pada posisi yang sesuai dengan kemampuan, kecakapan dan keahliaanya".

\section{Bentuk-bentuk Penempatan}

Penempatan karyawan bukan hanya diperuntukkan bagi mereka yang baru masuk menjadi karyawan tetapi juga karyawan lama dalam posisi dan jabatan baru. Teori sumber daya manusia mutakhir menekankan bahwa penempatan tidak hanya berlaku bagi karyawan lama yang mengalami alih tugas dan mutasi (P. Siagian, 1998). Pengertian tersebut dapat dikatakan bahwa penempatan dapat berbentuk seperti promosi, mutasi, dan demosi. Promosi adalah proses menaikkan tenaga kerja kepada kedudukan yang lebih bertanggung jawab. Kenaikan tersebut tidak terbatas pada kedudukan manajerial saja, tetapi mencakup setiap penugasan kepada pekerjaan yang lebih berat atau kebasan beroperasi tetapi kurang penyeliaan. Promosi biasanya diimbangi dengan kenaikan kompensasi bagi tenaga kerja yang bersangkutan Siswanto (2005) dalam Endang (2019).

Mutasi adalah kegiatan memindahkan tenaga kerja dari suatu tempat kerja ke tempat kerja lain. mutasi dapat didefinisikan sebagai kegiatan ketenagakerjaan yang berhubungan dengan proses pemindahan fungsi, tanggung jawab, dan status ketenagakerjaan tenaga kerja ke situasi tertentu dengan tujuan agar tenaga kerja yang bersangkutan memperoleh kepuasan kerja yang mendalam dan dapat memberikan prestasi kerja yang semaksimal mungkin kepada perusahaan Siswanto, (2005). Dalam Endang (2019). Menurut Hasibuan demosi yaitu pemindahan karyawan dari suatu jabatan ke jabatan yang lebih rendah di dalam suatu organisasi, wewenag, tanggung jawab, pendapat, serta statusnya semakin rendah (Hasibuan, 2001). Dalam Surya (2017) Menurut Sikula dalam Hasibuan demosi adalah suatu perpindahan dalam suatu organisasi dari satu posisi ke lainnya yang melibatkan penurunan gaji dan status (Hasibuan, 2001) dalam Surya (2017).

\section{Faktor-faktor yang dipertimbangkan dalam penempatan karyawan}

Sastrohadiwiryo (2002) dalam Surya (2019) menyatakan bahwa sebelum menempatkan tenaga kerja di tempat mereka bekerja terlebih dahulu mempertimbangkan beberapa faktor sebagai berikut: (1) Latar Belakang Pendidikan; (2) Pengalaman Kerja; (3) Kesehatan Fisik dan Mental; (4) Status Perkawinan dan (5) Faktor Umur. Sedangkan, menurut Wahyudi (2003) dalam Endang (2019) menyatakan melakukan penempatan karyawan hendaknya mempertimbangkan factor pendidikan, pengetahuan kerja, keterampilan kerja, dan pengalaman kerja. Pendidikan yang harus dimiliki oleh seorang karyawan, pendidikan minimum yang disyaratkan meliputi: (1) Pendidikan yang disyaratkan; (2) Pendidikan alternatif.

Pengetahuan yang yang harus dimiliki oleh seorang karyawan dengan wajar yaitu pengetahuan kerja ini sebelum ditempatkan dan yang baru diperoleh pada waktu karyawan tersebut bekerja dalam pekerjaan tersebut. 
Pengaruh Gaya Kepemimpinan Transaksional... Keterampilan kerja adalah kecakapan atau keahlian untuk melakukan suatu pekerjaan yang harus diperoleh dalam praktek, keterampilan kerja ini dapat dikelompokan menjadi 3 (tiga) kategori yaitu: (1) Keterampilan mental, seperti menganalisa data, membuat keputusan dan lain-lain, (2) Keterampilan fisik, seperti membetulkan listrik, mekanik dan lain lain serta (3) Keterampilan sosial, seperti mempengaruhi orang lain, mewarkan barang atau jasa dan lain-lain. Pengalaman kerja. Pengalaman seorang karyawan untuk melakukan pekerjaan tertentu. Pengalman kerja dapat menjadi bahan pertimbangan untuk: (1) Pekerjaan yang harus ditempatkan serta (2) Lamanya melakukan pekerjaan

\section{Iklim Kerja Karyawan}

Menurut Fisher and Fraser (1990), dalam Juni (2019) Iklim kerja karyawan didefinisikan sebagai seperangkat atribut yang memberi warna atau karakter, spirit, ethos, suasana batin, dari setiap karyawan. Lebih lanjut secara operasional pengertian iklim dalam konteks cuaca menurut Wahyudi, dkk. (2003), iklim kerja karyawan diukur dengan menggunakan rata-rata dari persepsi komunitas karyawan terhadap aspek-aspek yang menentukan lingkungan kerja dengan menggunakan angket. Pidarta (1995) dalam Donni, (2019), menyatakan beberapa faktor yang dapat berpengaruh terhadap iklim kerja karyawan berkaitan dengan; penempatan karyawan, pembinaan antar hubungan dan komunikasi, dinamisasi dan penyelesaian konflik, peningkatan lingkungan kerja serta lingkungan belajar.

\section{Kinerja Karyawan}

Agus Dharma (2003) dalam Priansa, (2018), mengatakan hampir semua cara pengukuran kinerja mempertimbangkan kuantitas, kualitas, dan ketepatan waktu. Kuantitas, yaitu jumlah yang harus diselesaikan atau dicapai. Kualitas, yaitu mutu yang harus dihasilkan (baik tidaknya). Pengukuran kualitatif keluaran mencerminkan pengukuran atau tingkat kepuasan yaitu seberapa baik penyelesaiannya. Ketepatan waktu, yaitu sesuai tidaknya dengan waktu yang direncanakan.

Menurut Mathis, Jackson (2006) dalam Lumingkewas, Cindy (2019) yang menjadi indikator dalam mengukur kinerja atau prestasi karyawan adalah kuantitas, kualitas, pemanfaatan waktu, dan kerja sama. Kuantitas kerja, yaitu volume kerja yang dihasilkan dalam kondisi normal. Kualitas kerja, yaitu dapat berupa kerapian ketelitian dan keterkaitan hasil dengan tidak mengabaikan volume pekerjaan. Pemanfaatan waktu, yaitu penggunaan masa kerja yang disesuaikan dengan kebijaksanaan perusahaan atau lembaga pemerintahan. Kerjasama, yaitu kemampuan menangani hubungan dengan orang lain dalam pekerjaan.

\section{METODE PENELITIAN}

Penelitian yang digunakan dalam penelitian ini adalah explanatory research yaitu penelitian yang menjelaskan hubungan kausal antara variabelvariabel penelitian melalui pengujian hipotesis yang dirumuskan sebelumnya. Penelitian ini bertujuan untuk membuktikan bahwa adanya pengaruh variabel 
Agusthina Risambessy, Paulus L. Wairisal

bebas yang terdiri dari gaya kepemimpinan transaksional, penempatan kerja dan iklim kerja terhadap kinerja karyawan. Penelitian ini dilaksanakan pada kantor PT. BPR Modern Express Ambon yang merupakan kantor pusat dan juga kantor-kantor cabang PT. BPR Modern Express (kantor cabang Tual, Masohi, Namlea, Piru, Saumlaki dan Nmarole). Dengan objek penelitian adalah pegawai PT BPR Modern Express karena merupakan satu-satunya BPR di Ambon dan telah mempunyai beberapa cabang di beberapa kabupaten di Maluku. Menurut Sugiyono (2009) dalam Atika (2017) Sampling Jenuh adalah teknik penentuan sampel bila semua anggota populasi digunakan sebagai sampel sebanyak 94 orang.

\section{Identifikasi Variabel Penelitian}

Gaya Kepemimpinan Transaksional (X1) Bass pada tahun 1985 mendefinisikan kepemimpinan transaksional Farida (2017) menurut menyatakan bahwa karakteristik kepemimpinan transaksional ditunjukkan oleh tiga dimensi, yaitu: (1) Contingent reward atau imbalan kontingen (X1.1), (2) Active management by exception atau manajemen eksepsi aktif (X1.2) serta (3) Pasive management by exception (X1.3). Penempatan Kerja (X2). Sastrohadiwiryo (2002) menyatakan menempatkan tenaga kerja: (1) Pendidikan (X2.1), (2) Keterampilan (X2.2), (3) Kesehatan Fisik dan Mental (X2.3). Iklim Kerja (X3) Nunik (2017) Iklim Kerja Karyawan (X) Adalah perpaduan antara manajemen dan sumber daya yang ada untuk melaksanakan kegiatan di perusahaan sesuai dengan tugas masing-masing. Iklim kerja terdiri dari: kompensasi, kerjasama tim, kesesuaian kerja, pembagian tugas dan kebijakan organisasi. Definisi sub variabel iklim kerja sebagai berikut: (1) Kompensasi (X3.1), (2) Kerjasama tim (X3.2), (3) Kesesuaian kerja (X3.3), (4) Pembagian tugas (X3.4), )5) Kebijakan organisasi (X3.5).

Dessler (2009) berpendapat bahwa Kinerja karyawan adalah prestasi aktual karyawan dibandingkan dengan prestasi yang diharapkan dari karyawan. Prestasi kerja yang diharapkan adalah prestasi standar yang disusun sebagai acuan sehingga dapat melihat kinerja karyawan sesuai dengan posisinya dibandingkan dengan standar yang dibuat. Selain itu dapat juga dilihat kinerja dari karyawan tersebut terhadap karyawan lainnya. Bernardin dan Russel (2001) mengemukakan enam kriteria primer yang digunakan untuk mengukur kinerja karyawan yang akan digunakan dalam penelitian ini antara lain: (1) Kualitas atau Quality (Y1.1) yaitu tingkat sejauh mana proses atau hasil pelaksanaan kegiatan pelayanan dicapai dengan mengutamakan mutu dan ketelitian. (2) Kuantitas atau Quantity (Y1.2), merupakan jumlah yang dihasilkan melalui tanggung jawab dan kewajiban yang diberikan sesuai jam kerja atau melebihi jam kerja, (3) Timelines (Y1.3), merupakan lamanya suatu kegiatan diselesaikan secara cepat dan tepat waktu, (4) Pengetahuan tentang pekerjaan atau job knowledge (Y1.4), luasnya pengetahuan mengenai pekerjaan dan ketrampilan berdasarkan standar kerja yang telah ditentukan, (5) Kesediaan bekerja sama dengan orang lain (cooperation) (Y1.5) serta (6) Semangat dalam melaksanakan tugas-tugas baru dan dalam memperbesar tanggung jawab atau initiative (Y1.6). 


\section{HASIL DAN PEMBAHASAN \\ Hasil}

Pengaruh Gaya Kepemimpinan Transaksional...

Pada pengolahan data dengan menggunakan regresi linear, dilakukan untuk membuktikan hubungan antara variabel independen dan variabel dependen, yakni pengaruh kepemimpinan transaksional (X1), penempatan kerja (X2), dan iklim kerja (X3) terhadap kinerja karyawan (Y) pada PT. Bank Perkreditan Rakyat Modern Express Ambon. Hasil perhitungan regresi berganda dapat dilihat pada tabel 1 dibawah ini :

Tabel 1. Hasil Analisis Regresi Berganda

\begin{tabular}{ccccc}
\hline Variabel & $\begin{array}{c}\text { Standardized } \\
\text { Coefficients }\end{array}$ & t hitung & Sig. & Keterangan \\
& $(\mathrm{B})$ & & & \\
\hline Konstanta & - & 3.027 & 0.005 & \\
Gaya Kepemimpinan & 0.195 & 2.699 & 0.008 & Signifikan \\
Transaksional (X1) & & & & \\
Penempatan Kerja & 0.424 & 4.158 & 0.000 & Signifikan \\
X2) & & & & \\
Iklim Kerja (X3) & 0.624 & 4.548 & 0.000 & Signifikan \\
R & & 0.677 & & \\
R Square & & 0.459 & & \\
Adjust R Square & & 0.447 & & \\
F hitung & & 40.078 & & \\
Sign. F & & 0.000 & & \\
\hline
\end{tabular}

Model regresi berdasarkan hasil analisis dengan bantuan program SPSS 27 dapat dibentuk suatu persamaan regresi sebagai berikut:

$\mathrm{Y}=0.195 \mathrm{X} 1+0.324 \mathrm{X} 2+0.324 \mathrm{X} 3$

Adapun interpretasi dari persamaan tersebut adalah; pertama, $\beta 1=$ 0.195 nilai parameter atau koefisien regresi $\beta 1$ menjelaskan bahwa setiap variabel kepemimpinan transksional (X1) akan meningkatkan kinerja karyawan PT. Bank Perkreditan Rakyat Modern Express Ambon (Y) akan meningkat sebesar nilai koefisien regresi $\beta 1$ atau dengan kata lain peningkatan kinerja karyawan PT. Bank Perkreditan Rakyat Modern Express Ambon dibutuhkan variabel kepemimpinan transaksional sebesar 0.195, dengan asumsi variabel lain tetap. Kedua, $\beta 2=0.324$ nilai parameter atau koefisien regresi $\beta 2$ menjelaskan bahwa setiap peningkatan variabel penempatan kerja (X2) berpengaruh signifikan positif terhadap Kinerja Karyawan PT. Bank Modern Express Ambon maka kinerja karyawan PT. Bank Perkreditan Rakyat Modern Express Ambon sebesar nilai koefisien regresi $\beta 2$ 
Agusthina Risambessy, Paulus L. Wairisal

atau dengan kata lain setiap peningkatan kinerja karyawan PT. Bank Perkreditan Rakyat Modern Express Ambon (Y) dibutuhkan variabel penempatan kerja sebesar 0.324, dengan asumsi variabel yang lain tetap.

Ketiga, $\beta 3=0.324$ nilai parameter atau koefisien regresi $\beta 3$ ini menjelaskan bahwa setiap variabel iklim kerja (X3).akan meningkatkan kinerja karyawan PT. Bank Perkreditan Rakyat Modern Express Ambon, sebesar nilai koefisien regresi $\beta 3$ atau dengan kata lain setiap peningkatan kinerja karyawan PT. Bank Perkreditan Rakyat Modern Express Ambon dibutuhkan variabel iklim kerja sebesar 0.324 , dengan asumsi variabel bebas yang lain tetap.

Tabel 2. Hasil Pengujian Hipotesis

\begin{tabular}{|c|c|c|}
\hline Hipotesis & Nilai & Keterangan \\
\hline $\begin{array}{l}\text { Kepemimpinan transaksional } \\
\text { berpengaruh positif terhadap kinerja } \\
\text { karyawan }\end{array}$ & $\begin{array}{l}t=2.699 \\
t \text { tabel }=1.658 \\
\text { Sig }=0.008\end{array}$ & $\begin{array}{l}\text { Tolak H0 dan } \\
\text { Terima Ha (H1 } \\
\text { diterima) }\end{array}$ \\
\hline $\begin{array}{l}\text { Penempatan kerja berpengaruh } \\
\text { positif terhadap kinerja karyawan }\end{array}$ & $\begin{array}{l}t=4.158 \\
t \text { tabel }=1.658 \\
\text { Sig }=0.000\end{array}$ & $\begin{array}{l}\text { Tolak H0 dan } \\
\text { Terima Ha (H1 } \\
\text { diterima) }\end{array}$ \\
\hline $\begin{array}{l}\text { Iklim kerja berpengaruh positif } \\
\text { terhadap kinerja karyawan }\end{array}$ & $\begin{array}{l}t=4.158 \\
t \text { tabel }=1.658 \\
\text { Sig }=0.000\end{array}$ & $\begin{array}{l}\text { Tolak H0 dan } \\
\text { Terima Ha (H1 } \\
\text { diterima) }\end{array}$ \\
\hline
\end{tabular}

\section{Pembahasan \\ Pengaruh Gaya Kepemimpinan Transaksional Terhadap Kinerja Karyawan}

Hasil penelitian ini membuktikan bahwa Gaya kepemimpinan transaksional berpengaruh nyata terhadap kinerja karyawan PT. Bank Modern Express Ambon. Hal ini berarti bahwa gaya kepemimpinan transaksional dengan imbalan kontingen item: pimpinan memberikan pedoman kerja kepada bpk/ibu untuk melakukan pekerjaan, pimpinan memberikan imbalan, melaksanakan pekerjaan yang diperintahkan dengan baik akan meningkatkan kinerja karyawan PT. Bank Modern Express Ambon. gaya kepemimpinan transaksional dengan manajemen ekspetasi aktif item: pimpinan melakukan tindakan perbaikan atas kesalahan bawahan, pemimpin mengawasi pekerjaan bawahan secara langsung agar sesuai dengan standar kerja yang ditetapkan, pimpinan mengawasi pekerjaan bawahan secara langsung agar hasil kerja sesuai dengan prosedur akan meingkatkan kinerja karyawan PT. Bank Modern Express Ambon, gaya kepemimpinan transaksional dengan manajemen eksepsi pasif item: pimpinan memantau kesalahan yang dilakukan bawahan dalam bekerja, pimpinan memberikan peringatan kepada bawahan apabila terjadi kesalahan dalam proses kerja, pimpinan memberikan sanksi apabila terjadi kepada bawahan jika terjadi kesalahan dalam proses kerja akan meningkatkan kinerja karyawan PT. Bank Modern Express Ambon. 
Pengaruh Gaya Kepemimpinan Transaksional...

Hal ini menunjukan bahwa gaya kepemimpinan transaksional yang diterapkan pada PT. Bank Modern Express Ambon dapat meningkatkan kinerja karyawan kinerja karyawan PT. Bank Modern Express Ambon. Hal ini berarti bahwa jika gaya kepemimpinan transaksional ditingkatkan lagi maka gaya kepemimpinan transaksional akan semakin meningkat pada PT. Bank Modern Express Ambon. Secara deskriptif tanggapan responden pada variabel gaya kepemimpinan transaksional rata-rata responden menyatakan sangat bagus/baik, hal ini ditunjukan dengan nilai mean: 4.2. hasil penelitian ini menjelaskan bahwa dengan gaya kepemimpinan transaskasional yang diterapkan dapat meningkatkan kinerja karyawan terhadap kinerja karyawan PT. Bank Modern Express Ambon.

Penelitian ini mendukung hasil penelitian Musnadi, Mukhlis Yunus (2012) Pengaruh Hasil peneletian membuktikan bahwa Kepemimpinan transaksional dalam memfokuskan perhatiannya pada proses pertukaran atau imbalan yang didasarkan pada kesepakatan mengenai klasifikasi sasaran, standar kerja, penugasan kerja dan penghargaan memiliki pengaruh yang signifikan terhadap kinerja karyawan. Kepemimpinan transformasional dalam memberikan motivasi dengan menitikberatkan pada perilaku untuk membantu tranformasi antara karyawan dengan perusahaan memiliki pengaruh yang signifikan terhadap kinerja karyawan. Menolak hasil penelitian Munawaroh (2018)

Perbedaan penelitian ini adalah menggunakan gaya kepemimpinan transaksional dengan indikator yang berbeda. Penelitian ini juga mendukung konsep yang dikembangkan oleh menurut Bass (1990) kepemimpinan transaksional memiliki karakteristik sebagai berikut: Contingent reward, Orientation work, Active management by exception, Responsiveness, dan Pasive management by exception.

\section{Pengaruh Penempatan Kerja Terhadap Kinerja Karyawan}

Hasil uji statistik menunjukan terdapat pengaruh signifikan positif pada penempatan terhadap kinerja karyawan PT. Bank Modern Express Ambon. Hipotesis diterima. Hal ini menunjukan bahwa penempatan berpengaruh nyata terhadap kinerja karyawan PT. Bank Modern Express Ambon. Hal ini memberi makana bahwa penempatan kerja dengan indikator pendidikan item: penempatan karyawan sesuai dengan jenjang pendidikan yang dimiliki, penempatan karyawan sesuai pengetahuan yang dimiliki, penempatan kerja sesuai dengan keahlian yang dimiliki dapat meningkatkan kinerja karyawan terhadap kinerja karyawan PT. Bank Modern Express Ambon, penempatan pegawai dengan indikator ketrampilan item: penempatan karyawan sesuai dengan pengalaman kerja, penempatan karyawan sesuai dengan ketrampilan yang dimiliki, penempatan karyawan sesuai dengan kemampuan, indikator kesehatan fisik dan mental, penempatan karyawan sangat mempertimbangkan kondisi fisik, penempatan karyawan sangat mengutamakan mental karyawan akana meningkatkan kinerja karyawan PT. Bank Modern Express Ambon. 
Agusthina Risambessy, Paulus L. Wairisal

Secara deskriptif tanggapan responden pada variabel penempatan kerja rata-rata responden menyatakan sangat bagus/baik, hal ini ditunjukan dengan nilai mean: 4.2. Hasil penelitian ini menjelaskan bahwa jumlah penempatan kerja yang diberikan kepada karyawan akan meningkatkan kinerja. Penelitian ini mendukung hasil penelitian Asri Nur Fadilah, Abdul Hakim, Siswidiyanto (2011), Hasil analisis menunjukkan terdapat pengaruh yang signifikan antara kesesuaian pengetahuan, kesesuaian kemampuan dan kesesuaian keahlian terhadap kinerja pegawai. Juga penelitian Dwi Ade Putra (2010) Hasil penelitian membuktikan terdapat pengaruh signifikan positif penempatan kerja dengan kinerja pegawai pada Dinas Perindustrian dan Perdagangan Provinsi Riau. Penelitian ini juga mendukung konsep yang dikembangkan oleh Sastrohadiwiryo (2002) menyatakan bahwa sebelum menempatkan tenaga kerja di tempat mereka bekerja terlebih dahulu mempertimbangkan beberapa faktor sebagai berikut: latar belakang pendidikan, pengalaman kerja, kesehatan fisik dan mental, status perkawinan serta faktor umur. Menurut Wahyudi yang dikutip suwatno (2003) dalam melakukan penempatan karyawan hendaknya mempertimbangkan faktor-faktor sebagai berikut: pendidikan, pengetahuan kerja, keterampilan kerja serta pengalaman kerja.

\section{Pengaruh Iklim Kerja Terhadap Kinerja Karyawan}

Hasil penelitian membuktikan bahwa terdapat pengaruh signifikan positif Iklim organisasi terhadap kinerja karyawan dengan indikator kompensasi diberikan sesuai pengalaman kerja yang dimiliki, sistem promosi berlaku bagi karyawan yang berprestasi, perusahaan memberi pujian bagi karyawan yang berprestasi, insentif yang diterima sesuai dengan jabatan yang dimiliki, indikator kerjasama item: tim dengan atasan baik, kerjasama tim dengan unit penunjang baik, indikator kesesuaian kerja item: pekerjaan yang harus diselesaikan sesuai beban kerja, pekerjaan yang harus diselesaikan melebihi beban kerja, indikator pembagian tugas item: bekerja sesuai tanggung jawab yang diberikan, bekerja sesuai kewenangan yang diberikan, indikator kebijakan organisasi, item: perusahaan menerima saran-saran melalui kotak saran dalam rangka perbaikan, perusahaan menerima saran secara langsung dalam rangka perbaikan akan meningkatkan kinerja karyawan.

Secara deskriptif tanggapan responden pada variabel iklim organisasi rata-rata responden menyatakan sangat bagus/baik, hal ini ditunjukan dengan nilai mean: 3.9. hasil penelitian ini menjelaskan bahwa dengan iklim organisasi diciptakan pada PT. Bank Modern Express Ambon. Penelitian ini mendukung hasil penelitian Lestariningsih (2012), Hasil penelitian membuktikan terdapat pengaruh secara serempak kompensasi, komitmen karyawan, lingkungan kerja, dan iklim kerja terhadap kinerja karyawan UD. Sinar badi Sidoarjo. Terdapat pengaruh secara parsial iklim kerja terhadap kinerja karyawan UD. Sinar Abadi Sidoarjo. Penelitian ini mendukung konsep yang dikembangkan upaya dalam penciptaan iklim kerja yang kondusif menurut (Gilles, 1996: Murlis, 2004), para ahli dapat dilakukan dengan cara: kesesuaian kerja: Tanggung jawab: Penghargaan, Hubungan kerja sama: Kejelasan organisasi. Peran penting iklim kerja di perusahaan, Rentoul at.al., (1997), dalam (Muklis 2018) bahwa ikim kerja karyawan dicerminkan oleh 4 
Pengaruh Gaya Kepemimpinan Transaksional... (empat) indikator yaitu; 1) Penempatan karyawan, 2) Pembinaan antar Hubungan dan Komunikasi, 3) Dinamisasi dan penyelesaian konflik, 4) Peningkatan Lingkungan Kerja karyawan.

\section{SIMPULAN}

Gaya kepemimpinan transaksional dengan indikator imbalan kontingen indikator manajemen ekspetasi aktif indicator manajemen eksepsi pasif, mempunyai pengaruh signifikan positif terhadap kinerja karyawan PT. Bank Modern Express Ambon. Penempatan kerja dengan indicator Pendidikan, indikator ketrampilan, indikator kesehatan fisik dan mental, berpengaruh signifikan positif terhadap Kinerja Karyawan PT. Bank Modern Express Ambon. Iklim kerja dengan indikator kompensasi indikator kerjasama indikator kesesuaian kerja indikator pembagian tugas indikator kebijakan organisasi, berpengaruh signifikan positif terhadap Kinerja Karyawan PT. Bank Modern Express Ambon.

\section{DAFTAR PUSTAKA}

Anriani, J. J. (2017). Dampak Penempatan dan Restrukturisasi Perusahaan Terhadap Kinerja Karyawan, Jurnal Akuntansi dan Manajemen. Vol 11, No. 1

Antasari, S. M. (2019). Pengaruh Gaya Kepemimpinan Transaksional Penempatan Kerja Kepuasan Kerja Dan Motivasi Kerja Terhadap Kinerja Karyawan Pada PT. Jaya Abadi Tanjung Pinang, Prosiding Seminar Nasional Darmajaya Vol 1, Institut Informatika dan Bisnis Darmajaya.

Dessler. (2009). Manajemen Sumber Daya Manusia Perusahaan. Bandung: PT Remaja Rosdakarya.

Dewi, A. K. (2018). Manajemen Sumber Daya Manusia, Malang: UMM Pres

Dewitasari, E. W. T. (2019). Perencanaan dan Pengembangan Sumber Daya Manusia, Bandung: Alfabeta

Fadilah, A. N., Hakim, A., dan Siswidiyanto. (2011). Manajemen Sumber Daya Manusia Perusahaan, Bandung: PT. Remaja Rosdakarya

Fajar, M. (2017). Pengaruh Kepemimpinan Transaksional dan Transformasional Terhadap Kinerja. Jurnal Psikologi dan Manajemen Vol. 4, No. 2

Farida, Paisjihadin, P. P., dan Sumbara, D. T. (2018). Pengaruh Iklim Kerja dan Penempatan Kerja Terhadap Kinerja (Studi pada Pegawai Dinas Perdagangan Provinsi Sulut), Jurnal Manajemen dan Wirausaha, Vol. 3, No. 2

Farida. (2017). Pengaruh Gaya Kepemimpinan Transaksional dan Penempatan Kerja dan Kepuasan Kerja Terhadap Kinerja Karyawan Pada Karyawan Pabrik Keramik Di Mojosari, Jurnal Ilmu Manajemen, Vol 7, No. 2

Fitria. (2019). Penempatan Karyawan BUMN (Teori dan Praktik), Jakarta: PT. Raja Grafindo Persada

Hasbala dan Ambarini. (2019). Pengaruh Penerapan gaya kepemimpinan transaksional, penempatan kerja dan iklim kerja terhadap kinerja karyawan dan kepuasan kerja sebagai Variabel Mediasi pada karyawan Pabrik Keramik di Mojosari, Jurnal Kajian Manajemen Bisnis, Vol. II, No. 1 
Agusthina Risambessy, Paulus L. Wairisal

Kamerusaman dan Dwihartini. (2020). Gaya Kepemimpinan Transaksional dan Transformasional, kemampuan kerja dan iklim kerja pada karyawan PT. Anugrah Lahan Sibela Maluku Utara. Jurnal Keuanhan dan Manajemen Vol. III, No. 1

Kasmir. (2016). Manajemen Sumber Daya Manusia, Edisi Kedua, Jakarta: PT. Prehallindo

Lestariningsih, M. (2012). Pengembangan Sumber Daya Manusia. Jakarta: Andy

Lumingkewas, Cindy. (2019). Evaluasi Kinerja Sumber Daya Manusia. Jakarta: Salemba Empat. Jurnal Manajemen Keuangan dan Bisnis. Vol. 8, No. 2

Munawaroh. (2018). Penempatan Karyawan sebagai Motivasi Kerja dan Pengembangan Sumber Daya Manusia. Jakarta: Andy

Musnadi, Mukhlis Yunus. (2012). Perencanaan dan Pengembangan Sumber Daya Manusia. Bandung: Alfabeta

Natalia, H., dan Murti, H. (2018). Pengaruh Gaya Kepemimpinan Transaksional dan penempatan karyawan terhadap kinerja karyawan dan kepuasan sebagai variable mediasi pada staf/karyawan PD. BPR Bank Jogja Kota Yogyakarta, Jurnal Psikologi dan Manajemen. Vol. 4, No. 1

Ningrum, A. N. S. (2018). Pengaruh gaya kepemimpinan transformasional dan Transaksional, penempatan kerja terhadap kinerja karyawan. Jurnal Bisnis dan Informatika, Vol. 4, No. 2

Nur, N. L. (2017). Pengaruh Gaya Kepemimpinan Transaksional kepuasan dan Penempatan Kerja Terhadap Kinerja Karyawan Pada PT. Ratu Pola Bumi (RPB) Bandar Lampung, Prosiding Seminar Nasional Darmajaya Vol 1, Institut Informatika dan Bisnis Darmajaya.

Priansa. (2018). Faktor-Faktor Pengukuran Kinerja. Edisi Kedua. Jakarta: PT. Prehallindo

Putra, D. A. (2010). Indikator Pengukuran Kinerja (Teori dan Praktik), Jakarta: PT. Raja Grafindo Persada

Rorego, D. D. (2019). Penempatan Kerja dan Perampinagan Perusahaan. Jakarta: PT. Raja Grafindo Persada.

Sahrul, A. I. (2018). Manajemen SDM dalam Organisasi Publik dan Bisnis. Bandung: Alfabeta

Sastrohadiwiryo. (2002). Perencanaan Sumber Daya Manusia. Bandung: Alfabeta

Suryadi, A. A. (2018). Pengaruh gaya kepemimpinan transformasional dan transaksional serta penempatan kerja terhadap kepuasan dan kinerja karyawan Pada Bank Mandiri Cabang Sidoarjo. Jurnal Aplikasi Bisnis dan Manajemen, Vol. 3, No. 2

Suwatno. (2003). Perencanaan dan Pengembangan Manajemen Sumber Daya Manusia. Jakarta: Andy

Syam, M. N. (2018). Pengaruh Gaya Kepemimpinan Transaksional dan Iklim Kerja Terhadap Kinerja Karyawan (Studi Pada Karyawan PT. Mustika Jaya Brebes). Jurnal Kewirausahaan dan Manajemen, Vol .6 No.2

Takandengan, C., Marli, dan Sarli. (2019). Pengaruh Gaya Kepemimpinan Transaksional, Penempatan kerja dan Iklim Kerja terhadap kinerja karyawan pada karyawan Badan Pertanahan Provinsi Sumatra Utara. Jurnal Manajemen, Bisnis dan Informatika, Vol.2. No. 1

Wahid, J. S. (2019). Pengaruh Gaya Kepemimpinan Transformasional, Iklim 188| IQTISHODUNA Vol. 17 (2), 2021

http://ejournal.uin-malang.ac.id/index.php/ekonomi 
Pengaruh Gaya Kepemimpinan Transaksional...

Kerja dan Penempatan Kerja Terhadap Kinerja Karyawan Dengan Komitmen Organisasi Sebagai Variabel Mediasi Pada Perawat Kontrak Rumah Sakit Umum Citra BMC Padang, Jurnal Kajian Manajemen dan Wirausaha, Vol. 1, No. 1

Wijaya, A. (2017). Pengaruh Gaya Kepemimpinan Transaksional dan Iklim Kerja serta Kepuasan kerja Terhadap Kinerja Karyawan (Studi Pada Karyawan PT. Andika Jaya Utama Kepanjen) Jurnal Manajemen, Bisnis dan Kewirausahaan, Vol. 1, No. 1 